\title{
PYY Gene
}

National Cancer Institute

\section{Source}

National Cancer Institute. PYY Gene. NCI Thesaurus. Code C104810.

This gene is involved in gastrointestinal function. 